\title{
NO-Flurbiprofen Attenuates Excitotoxin-Induced Brain Inflammation, and Releases Nitric Oxide in the Brain
}

\author{
Costanza Prosperi, Carla Scali, Giancarlo Pepeu and Fiorella Casamenti* \\ Department of Pharmacology, University of Florence, Viale Pieraccini 6, 50139 Florence, Italy
}

Received February 27, 2001 Accepted March 27, 2001

\begin{abstract}
Brain inflammation underlies the pathogenesis of Alzheimer's disease (AD) and nonsteroidal anti-inflammatory drug therapy may delay the onset of AD. We investigated, in vivo, the effects of NOflurbiprofen on brain inflammation in rats injected with quisqualic acid into the nucleus basalis and on the release of nitric oxide from the drug in naive rat brains. We showed that the excitotoxin-induced microglia reaction, the expression of inducible nitric oxide synthase-positive cells and the production of interleukin$1 \beta$ and prostaglandin- $\mathrm{E}_{2}$ in the injected area were attenuated by the NO-flurbiprofen $(15 \mathrm{mg} / \mathrm{kg}$, p.o. $)$ treatment. An oral administration of NO-flurbiprofen $(25,50$ and $100 \mathrm{mg} / \mathrm{kg}$ ) to naive rats was followed by significant increases in cortical nitrite levels. This drug may have important therapeutic implications for the treatment of $\mathrm{AD}$.
\end{abstract}

Keywords: Nucleus basalis, Alzheimer's disease, Nitric oxide-releasing nonsteroidal anti-inflammatory drug, Inflammatory mediator

Recent studies have demonstrated a role for immune activation in the most common neurodegenerative disease in aging humans, namely Alzheimer's disease (AD) (1). Abnormal deposition of complement components, acutephase reactants, as well as various cytokines, and up-regulation of inducible cyclooxygenase (COX-2) are among the features detected in $\mathrm{AD}$ brain $(2,3)$. The neuritic plaques, a histopathological hallmark of the disease, are typically surrounded by reactive astrocytes and microglia, which are capable of producing and releasing proteases, complement components, reactive oxygen and nitrogen intermediates and cytokines. Epidemiological studies (1) reporting that chronic use of nonsteroidal anti-inflammatory drugs (NSAIDs) reduces the risk and delays the clinical expression of $\mathrm{AD}(4,5)$ and that $\mathrm{AD}$ and rheumatoid arthritis are diagnosed in the same individuals less frequently than expected (6) support the hypothesis that inflammation is closely related to the clinical manifestation of AD. Most NSAIDs have numerous gastrointestinal side effects (7) that significantly limit their usefulness in the long-term therapy that is necessary for $\mathrm{AD}$ patients (8).

A new class of nitric oxide (NO)-releasing NSAID derivatives, including NO-flurbiprofen (HCT-1026), generated by the incorporation of a nitroxybutyl moiety

*Corresponding author. FAX: +39-055-4271280

E-mail: fiorella@pharm.unifi.it through an ester linkage to the parent NSAID, exhibits, in experiments in animals and healthy volunteers, a reduced gastrointestinal toxicity when compared with the corresponding parent NSAID $(9-11)$. NO plays an important role in gastric mucosal defense, and it is believed that NO-NSAIDs spare the gastrointestinal tract by local release of NO. This leads to an increase in mucosal blood flow and thus to the prevention of the pathogenic events subsequent to the suppression of prostaglandin synthesis $(11,12)$.

We showed that quisqualic acid injection into the nucleus basalis (NB) of rats induces an intense glia reaction and the production of inflammatory mediators and that the administration of the NSAID nimesulide significantly attenuates the brain inflammatory reaction (13). The injection of the excitotoxin quisqualic acid into the NB results in loss of cholinergic neurones and has been used to induce a cholinergic hypofunction mimicking the cholinergic deficits of AD (14). The present study extends our previous work by characterizing the anti-inflammatory effect of NO-flurbiprofen in rats injected into the NB with quisqualic acid and by establishing, in naive rats, whether its administration is followed by NO increases in the brain. The inflammatory response was determined by observing the cellular changes in microglial cells and the induction of inducible nitric oxide synthase (iNOS) expression. In addition, the production of interleukin- $1 \beta$ (IL-1 $\beta$ ) and prostaglandin- $\mathrm{E}_{2}\left(\mathrm{PGE}_{2}\right)$ was measured in the injected NB. In order to determine 
whether the administration of NO-flurbiprofen resulted in an increase in brain NO, the levels of extracellular nitrite were measured by microdialysis in the cerebral cortex.

\section{MATERIALS AND METHODS}

\section{Animals}

Three-month old male Wistar rats (Harlan Nossan, Milan, Italy) weighing $230-250 \mathrm{~g}$ were used. The rats were housed in macrolon cages with ad libitum food and water and maintained on a 12 -h light/dark cycle at $23^{\circ} \mathrm{C}$ room temperature. All experiments were carried out according to the guidelines of the European Community's Council for Animal Experiments. All efforts were made to minimize animal suffering and to reduce the number of animals used.

\section{Quisqualic acid injection into the nucleus basalis and drug treatment}

An injection into the right NB of $0.5 \mu 1$ of $0.12 \mathrm{M}$ quisqualic acid (Sigma, Milan, Italy), dissolved in $50 \mathrm{mM}$ sodium phosphate buffer ( $\mathrm{pH} 7.4$ ), was made by means of a Hamilton microsyringe, under sodium pentobarbital (45 mg/kg, i.p.) anesthesia at the stereotaxic coordinates: $\mathrm{AP}=-0.2, \mathrm{~L}=-2.8$ from the bregma and $\mathrm{H}=7$ from the dura (14). Control rats were injected with saline solution. After the intracerebral injection of quisqualic acid, the rats were divided in two groups. One group received NOflurbiprofen $(15 \mathrm{mg} / \mathrm{kg}$, p.o.) for 7 days starting the same day of the quisqualic acid injection. This dose treatment was chosen on the basis of a previous report (15). The second group was treated with saline. In order to investigate the drug's effect on the formation of IL- $1 \beta$ in the injected $\mathrm{NB}$, another group of animals received a single oral administration of NO-flurbiprofen ( $15 \mathrm{mg} / \mathrm{kg}$, p.o.) $45 \mathrm{~min}$ prior to injection into the NB of quisqualic acid, and the animals were sacrificed $3 \mathrm{~h}$ after lesion. NO-flurbiprofen was kindly supplied from Nicox, Sophia-Antipolis, France.

\section{Nitrite levels}

To assess whether the administration of NO-flurbiprofen would result in an increase in NO in the brain, the levels of nitrite were measured in the cerebral cortex, by means of transversal microdialysis technique (16), after an oral administration of $15,25,50$ and $100 \mathrm{mg} / \mathrm{kg}$ or repeated oral administrations for 7 days of $15 \mathrm{mg} / \mathrm{kg}$. Under sodium pentobarbital $(45 \mathrm{mg} / \mathrm{kg}$, i.p.) anaesthesia, a 4-mm microdialysis tube (AN 69 membrane, molecular weight cut-off $>15 \mathrm{kDa}$ ) was inserted transversally into the brain (AP = $-0.5, \mathrm{H}=-2.5$ from bregma). On the following day, the membrane was perfused ( $3 \mu \mathrm{l} / \mathrm{min}$ ) with Ringer solution (147 mM NaCl, $1.2 \mathrm{mM} \mathrm{CaCl}_{2}, 4.0 \mathrm{mM} \mathrm{KCl}$ ), and after collecting 1 basal sample of 3 -h perfusion, the rats received an oral administration of NO-flurbiprofen at 15, 25, 50 or
$100 \mathrm{mg} / \mathrm{kg}$, and the corresponding sample of 3-h perfusion was collected. The nitrite levels in the dialysis perfusates were assayed spectrophotometrically. Five-hundred microliters of perfusate was mixed with $500 \mu \mathrm{l}$ of Griess reagent.

\section{Immunohistochemistry}

Under deep anesthesia, the rats were perfused transcardially with ice-cold paraformaldehyde solution (4\% in phosphate-buffer, $\mathrm{pH}$ 7.4). The brains were postfixed for $4 \mathrm{~h}$ and cryoprotected in $18 \%$ sucrose solution for at least $48 \mathrm{~h}$. Brains were cut in a cryostat throughout the injected area, in $30-\mu \mathrm{m}$-thick coronal sections and placed in phosphate-buffered saline (PBS) containing $0.1 \%$ sodium azide and stored at $4^{\circ} \mathrm{C}$ until used for immunohistochemistry.

Day 1: A monoclonal mouse antibody (1:400 dilution) OX-6 (PharMingen, San Diego, CA, USA) was used to detect activated microglial cells. iNOS was detected by means of a primary monoclonal mouse antibody (1:200 dilution) (Transduction Laboratories, Lexington, KY, USA). The sections were washed in PBS containing $0.3 \%$ Triton X-100 and then incubated free-floating overnight at room temperature (RT) with the primary antibody in PBS solution containing $5 \mathrm{mg} / \mathrm{ml}$ albumin, $0.3 \%$ Triton X-100 and $0.1 \%$ sodium azide.

Day 2: After washing in PBS, the sections were incubated for $1 \mathrm{~h}$ at RT with the secondary anti-rabbit or anti-mouse antibody (1:1000 dilution) (Vector Laboratories, Burlingame, CA, USA) in PBS solution containing $1 \mathrm{mg} / \mathrm{ml}$ albumin and $0.1 \%$ sodium azide. After incubation with the avidin-biotin-peroxidase complex (Vector kit) for $1 \mathrm{~h}$ at RT, the primary antibody was localized by diaminobenzidine$\mathrm{H}_{2} \mathrm{O}_{2}$ peroxidase; $\mathrm{NiCl}_{2}$ was used as an intensifier (dark purple color). At the end of the reaction, the sections were mounted on gelatin-coated slides, air dried and then washed, dehydrated and mounted. For light microscope examination and photography, a BX40 microscope (Olympus Optical Co., Ltd., Tokyo) was used.

\section{$I L-1 \beta$ and $P G E_{2}$ formation}

At $3 \mathrm{~h}$ or 7 days after quisqualic acid or saline injection into the NB, the rats were killed by decapitation, the brain quickly removed from the skull, and the NB area dissected out on ice, weighed and homogenized in ice in $20 \mathrm{vol}$ icecold buffer containing 1\% Nonidep P-40, 50 mM Hepes, $500 \mathrm{mM} \mathrm{NaCl}, 2 \mathrm{mM}$ phenylmethylsulfonyl fluoride and $5 \mu \mathrm{g} / \mathrm{ml}$ leupeptin (Sigma Chemical Co.). The homogenates were centrifuged at $3000 \mathrm{rpm}$ at $4^{\circ} \mathrm{C}$ for $15 \mathrm{~min}$, and the supernatants were removed. The concentrations of IL- $1 \beta$ and $\mathrm{PGE}_{2}$ were determined in $50-\mu 1$ samples using a commercially available rat specific ELISA kit and EIA kit (Biotrak; Amersham Life Science Ltd., Buckinghamshire, England), respectively. 


\section{Statistical analyses}

All results are reported as mean values \pm S.E.M. Analysis of variance one-way ANOVA followed by Fisher's post hoc multiple comparison test or Student's $t$-test were used when appropriate.

\section{RESULTS}

\section{Nitrite formation}

Figure 1 shows the effect of an oral administration of NO-flurbiprofen $(15,25,50$ and $100 \mathrm{mg} / \mathrm{kg})$ on cortical extracellular levels of nitrite. Within $3 \mathrm{~h}$ after the administration of 25,50 and $100 \mathrm{mg} / \mathrm{kg}$ of NO-flurbiprofen, the cortical nitrite levels were significantly increased by $43 \%$, $260 \%$ and $200 \%$, respectively, as compared to basal values. No significant increase in nitrite levels was brought about by $15 \mathrm{mg} / \mathrm{kg}$ of the drug either after a single administration or after repeated administrations for 7 days (data not shown).

\section{Immunohistochemical analysis and effects of NO-flurbipro- fen treatment}

As previously reported (13), quisqualic acid injection into the NB induced an intense transformation of microglial cells from a resting to an activated state, highlighted by phenotypic changes at the injection site and throughout the injected hemisphere. Seven days after quisqualic acid injection, many clusters of activated microglial cells, characterized by a bushy appearance with swollen cell bodies and

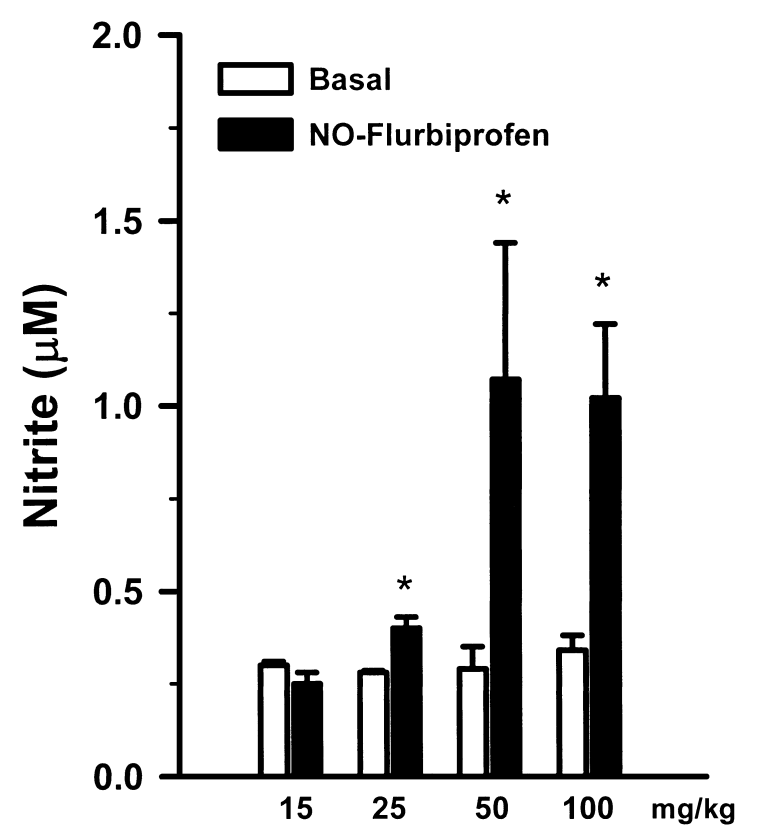

Fig. 1. Effect of a single administration of NO-flurbiprofen on extracellular nitrite levels in the cortex, detected by microdialysis in vivo. ${ }^{*} P<0.05$ vs respective basal value; Student's $t$-test. intensely stained short processes and some round-shaped microglial cells were observed around the injection site (Fig. 2: a and c). In saline-injected animals, only a small number of microglial cells was seen along the needle track in the injected NB (data not shown). Seven days after quisqualic acid injection into the $\mathrm{NB}$, many roundish iNOS-immunopositive cells were found around the injection site (Fig. 3a).

Seven days of NO-flurbiprofen treatment $(15 \mathrm{mg} / \mathrm{kg}$, p.o.) resulted in a strong attenuation of microglial reaction in the injected area (Fig. 2: b and d) as well as in all areas of the hemisphere ipsilateral to the injection site. The treatment also induced a significant reduction in the number of iNOS-positive cells in the injected site (Fig. 3b).

\section{$I L-1 \beta$ and $P G E_{2}$ formation}

Table 1 shows that quisqualic acid injection into the NB induced, $3 \mathrm{~h}$ after injection, more than a fivefold increase in IL-1 $\beta$ levels and, 7 days after injection, a threefold increase in the $\mathrm{PGE}_{2}$ concentration in the injected area in comparison with saline-injected rats. The increase in IL- $1 \beta$ levels was reduced by half by the administration of a single dose of NO-flurbiprofen (15 mg/kg, p.o.) $45 \mathrm{~min}$ before injection of quisqualic acid into the NB, and the increase in $\mathrm{PGE}_{2}$ formation was reduced by $70 \%$ by 7 days of NOflurbiprofen treatment.

\section{DISCUSSION}

The aims of this study were to establish whether the administration of NO-flurbiprofen was followed by NO increases in the brain and to investigate its anti-inflammatory effect in an animal model of brain neuronal degeneration associated with an inflammatory reaction. We demonstrated that local injection into the NB of the excitotoxin quisqualic acid induces activation of microglial cells and local production of inflammatory mediators. Furthermore, our findings demonstrate that oral administration of NOflurbiprofen attenuates the brain inflammatory reaction and, at a slightly higher dose, increases the concentration of $\mathrm{NO}$ in the brain.

In previous experiments, we demonstrated that rapid elevation in the concentration of $\mathrm{IL}-1 \beta$ in the quisqualic acid-injected area is significantly reduced by nimesulide pretreatment (13), and in the present study, this cytokine elevation was significantly reduced by pretreatment of animals with NO-flurbiprofen. Although the mechanisms underlying this effect have not been investigated, it is feasible that the reduced production of IL- $1 \beta$ by NO-flurbiprofen treatment might be related to inhibition of caspase-1 (interleukin-1 $\beta$-converting enzyme) and/or to inhibition of cellular transduction mechanisms (e.g., NF $\kappa$-B cascade), as reported for other NO-NSAID derivatives (17), and/or 

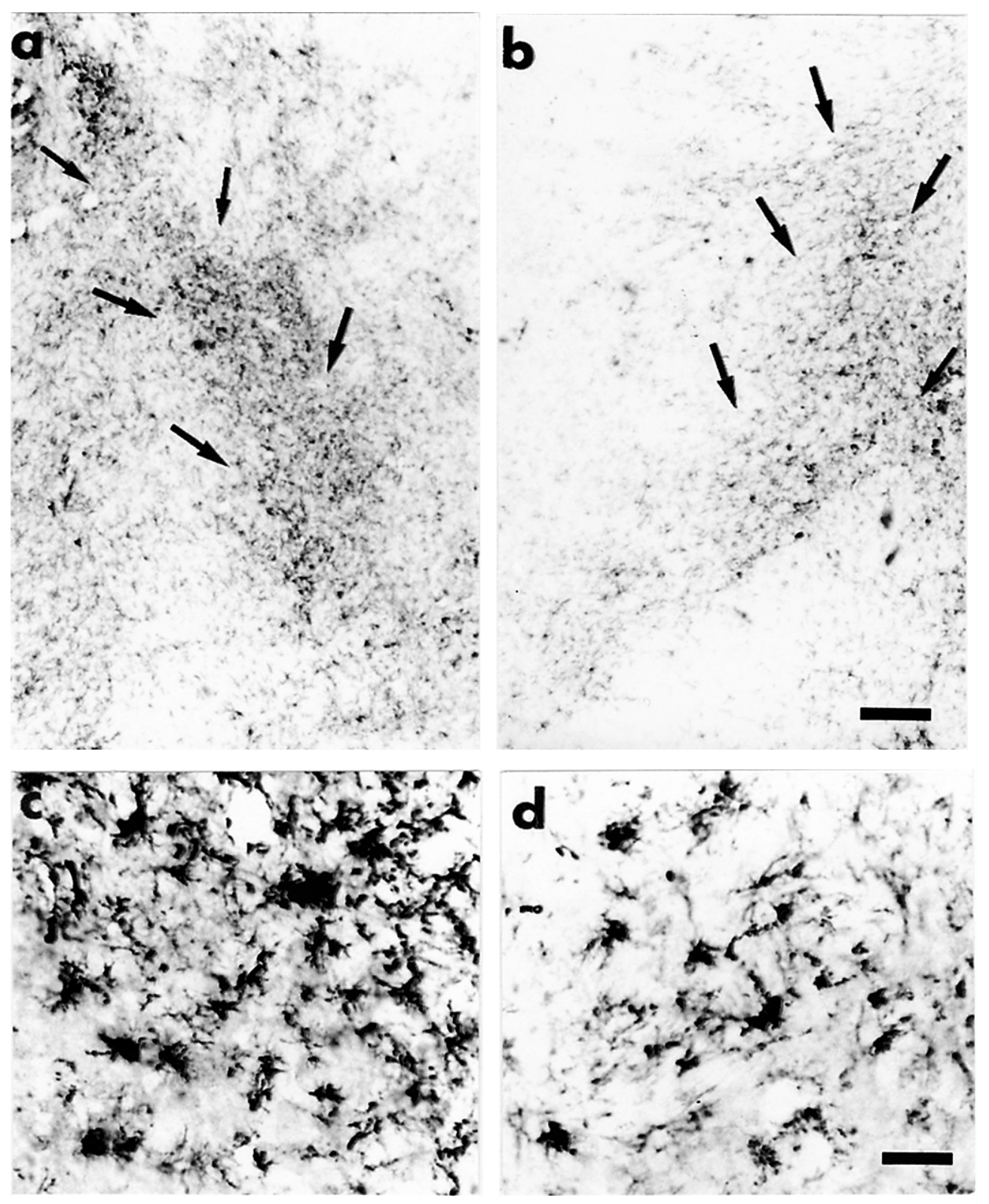

Fig. 2. Effect of NO-flurbiprofen treatment on the inflammatory reaction induced by the injection of the excitotoxin quisqualic acid into the NB. Activated microglial cells were stained by means of OX-6 antibody. Panels a and c: quisqualic acid-lesioned rat treated with saline, 7 days after lesion; panels $b$ and d: quisqualic acid-lesioned rat treated daily with NO-flurbiprofen $(15 \mathrm{mg} / \mathrm{kg})$, 7 days after lesion. Scale bars: panels a and b, $232 \mu \mathrm{m}$; panels c and d, $46 \mu \mathrm{m}$.

to activation of the DNA-binding transcription factor, the nuclear peroxisome proliferator-activated receptor- $\gamma$, as reported for some NSAIDs $(18,19)$. Previous observations have shown that the treatment of endotoxin-treated animals with NO-flurbiprofen significantly reduces inflammation within the CNS (15) and iNOS induction in the stomach (20). We now show that 7-day administration of NO-flurbiprofen attenuates quisqualic acid-induced brain inflammation, as indicated by the reduction in the reactive state of microglial cells, the number of iNOS-positive cells and the formation of $\mathrm{PGE}_{2}$ in the injected area. The anti-inflammatory properties of NO-flurbiprofen, as well as of the parent compound, are ascribed to their ability to inhibit both isoforms of the cyclooxygenase (COX) enzyme leading to the suppression of prostaglandin synthesis (21). Furthermore, interactions between $\mathrm{NO}$ and COX activity occur in inflammatory conditions (22). An inhibitory effect of NO released from nitroparacetamol on COX activity has been hypothesised as accounting for the anti-inflammatory and augmented antinociceptive activity of this compound as 

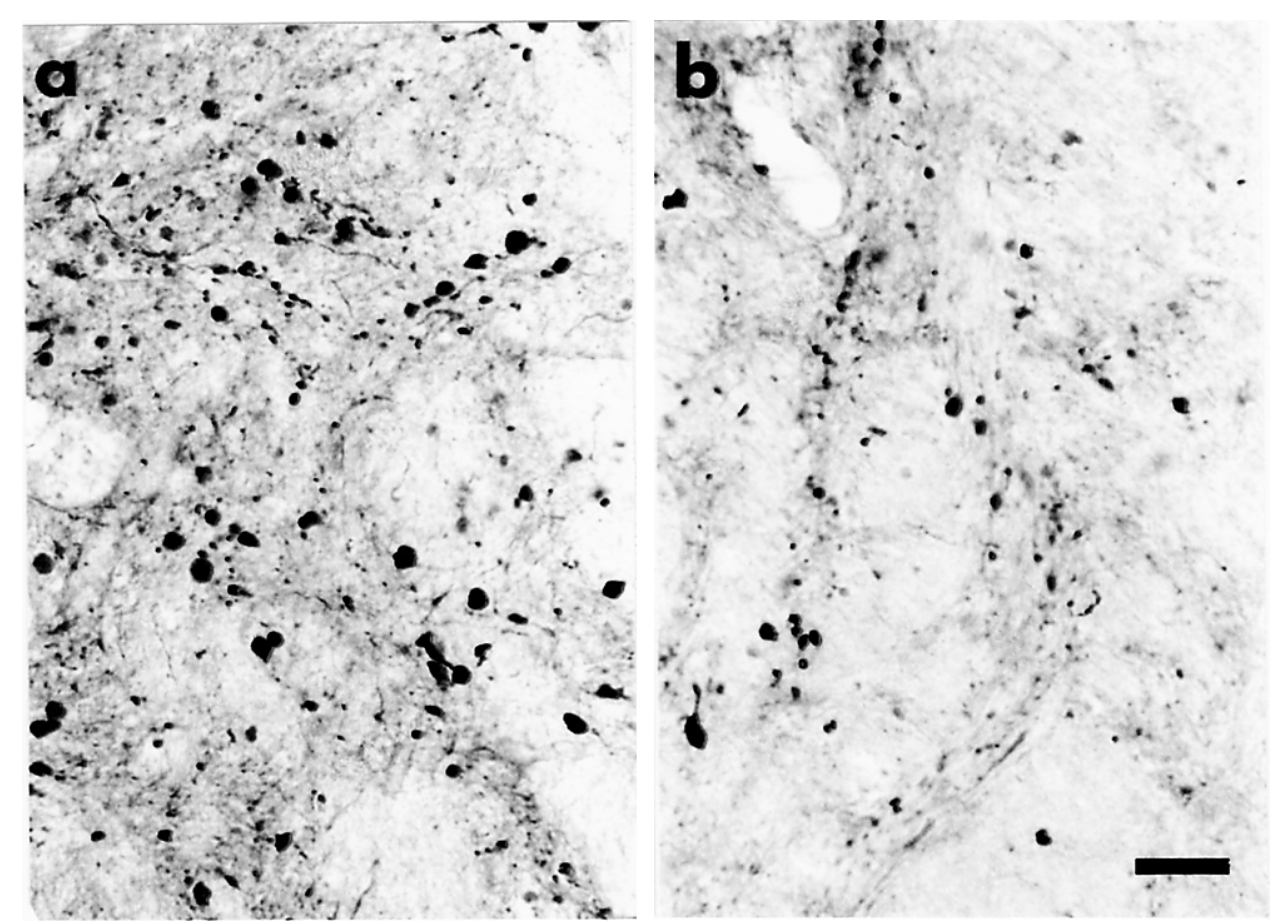

Fig. 3. Effect of NO-flurbiprofen treatment on the iNOS-immunopositive cells in the quisqualic acid injected NB. Panel a: quisqualic acid-lesioned rat treated with saline, 7 days after lesion; panel b: quisqualic acid-lesioned rat treated daily with NO-flurbiprofen $(15 \mathrm{mg} / \mathrm{kg}), 7$ days after lesion. Scale bar: $29 \mu \mathrm{m}$.

Table 1. Effect of NO-flurbiprofen on the IL- $1 \beta$ and $\mathrm{PGE}_{2}$ concentrations in the nucleus basalis injected with quisqualic acid

\begin{tabular}{lcc}
\hline & $\mathrm{Il}-1 \beta(\mathrm{pg} / \mathrm{ml})$ & $\mathrm{PGE}_{2}(\mathrm{pg} / \mathrm{sample})$ \\
\hline Saline & $16.6 \pm 2.5$ & $62.4 \pm 12.2$ \\
Quisqualic acid & $101.7 \pm 12^{*}$ & $250.2 \pm 35^{*}$ \\
Quisqualic acid + NO-flurbiprofen & $55.5 \pm 18^{\#}$ & $76.4 \pm 6^{\#}$ \\
\hline
\end{tabular}

$\mathrm{IL}-1 \beta$ and $\mathrm{PGE}_{2}$ concentrations in brain homogenates of the injected area were measured at $3 \mathrm{~h}$ and 7 days after injection, respectively. Statistical analysis: ${ }^{*} P<0.05$ vs saline-injected animals; ${ }^{\#} P<0.05$ vs quisqualic acid-injected animals, ANOVA and Fisher post-comparison test. Number of animals: $4-6$.

compared to the parent compound (11). Our experiments, demonstrating a significant elevation in nitrite levels in the cortex after acute administration of NO-flurbiprofen indicate that this drug releases NO in the brain. The need of a 3-h perfusate collection period may hide a short-lasting increase in nitrite levels after the administration of $15 \mathrm{mg}$ $/ \mathrm{kg}$ of NO-flurbiprofen. For this reason an involvement of NO released from the drug in attenuating the excitotoxininduced brain inflammatory reaction can not be completely ruled out. NO is an important biological mediator in maintaining the physiological condition in animals and humans. While NO at high levels is cytotoxic (23), at low levels it inhibits apoptosis in several cell models via post-translational $S$-nitrosylation/inactivation of caspase 1 and 3 (24,
25). A role for caspase activation and for caspase-mediated apoptotic death of neurones in $\mathrm{AD}$ and other neurodegenerative diseases has been supported by several recent studies $(26,27)$. Thus in neurodegenerative disorders, the NO released in the brain from NO-flurbiprofen, at doses slightly higher than that exhibiting an anti-inflammatory activity in rodents, might offer neuroprotective effects through an inhibition of caspase-mediated neurone apoptotic death.

In conclusion, we have shown that the excitotoxin-induced microglial reaction, the expression of iNOS-positive cells, as well as the production of IL- $1 \beta$ and $\mathrm{PGE}_{2}$ in the injected area were strongly attenuated by NO-flurbiprofen treatment. Furthermore, our data provide, for the first time, evidence in vivo that NO-flurbiprofen releases NO in the brain. Although the physiological relevance of this NO increase is presently unknown, possible neuroprotective effects on neurones, through a suppression of apoptosis, by NO released from NO-flurbiprofen in vivo, is envisaged. Thus this drug may have important therapeutic implications for the treatment of $\mathrm{AD}$ and other diseases involving a chronic inflammatory response.

\section{Acknowledgments}

This work was supported by a grant from Nicox, Sophia-Antipolis, France and supported in part by funds from the University of Florence and MURST, Italy. 


\section{REFERENCES}

1 McGeer EG and McGeer PL: The importance of inflammatory mechanisms in Alzheimer disease. Exp Gerontol 33, 371 - 378 (1998)

2 McGeer PL and McGeer EG: Inflammation of the brain in Alzheimer's disease: implications for therapy. J Leukoc Biol 65, 409 - 415 (1999)

3 Shepherd CE, Thiel E, McCann H, Harding AG and Halliday GM: Cortical inflammation in Alzheimer disease but not dementia with Lewy bodies. Arch Neurol 57, 817 - 822 (2000)

4 Breitner JCS, Welsh KA, Helms MJ, Gaskell PC, Gau BA, Roses AD, Pericak-Vance MA and Saunders AM: Delayed onset of Alzheimer's disease with nonsteroidal anti-inflammatory and histamine H2 blocking drugs. Neurobiol Aging 16, $523-530$ (1995)

5 Stewart WF, Kawas C, Corrada M and Metter EJ: Risk of Alzheimer's disease and duration of NSAID use. Neurology $\mathbf{4 8}$, $628-632$ (1997)

6 McGeer PL, McGeer EG, Rogers J and Sibley J: Anti-inflammatory drugs and Alzheimer disease. Lancet 335, 1037 (1990)

7 Wallace JL and Granger DN: The pathogenesis of NSAIDgastropathy - are neutrophils culprits? Trends Pharmacol Sci 13, 129 - 131 (1992)

8 Rogers J, Scott W, Lue L-F, Brachova L, Civin WH, Emmerling M, Shivers B, Walker D and McGeer PL: Inflammation and Alzheimer's disease pathogenesis. Neurobiol Aging 17, 681 686 (1996)

9 Burgaud JL, Benedini F, Robinson EM and del Soldato P: HCT-1026 flurbiprofen nitroxytlbutyl ester. Drugs Future 24, $858-861$ (1999)

10 Wallace JL, Reuter B, Cicala C, McKnight W, Grisham MB and Cirino G: Novel nonsteroidal anti-inflammatory drug derivatives with markedly reduced ulcerogenic properties in the rat. Gastroenterology 107, 173 - 179 (1994)

11 al-Swayeh OA, Clifford RH, del Soldato P and Moore PK: A comparison of the anti-inflammatory and anti-nociceptive activity of nitroaspirin and aspirin. Br J Pharmacol 129, 343 350 (2000)

12 al-Swayeh OA, Futter LE, Clifford RH and Moore PK: Nitroparacetamol exhibits anti-inflammatory and anti-nociceptive activity. Br J Pharmacol 130, 1453 - 1456 (2000)

13 Scali C, Prosperi C, Vannucchi MG, Pepeu G and Casamenti F: Brain inflammatory reaction in an animal model of neuronal degeneration and its modulation by an anti-inflammatory drug: implication in Alzheimer's disease. Eur J Neurosci 12, 1900 1912 (2000)

14 Casamenti F, Prosperi C, Scali C, Giovannelli L and Pepeu G: Morphological, biochemical and behavioural changes induced by neurotoxic and inflammatory insults to the nucleus basalis. Int J Devl Neurosci 16, 705 - 714 (1998)

15 Hauss-Wegrzyniak B, Willard LB, Del Soldato P, Pepeu G and Wenk GL: Peripheral administration of novel anti-inflammatories can attenuate the effects of chronic inflammation within the CNS. Brain Res 815, 36 - 43 (1999)

16 Casamenti F, Prosperi C, Scali C, Giovannelli L, Colivicchi MA, Faussone-Pellegrini MS and Pepeu G: Interleukin- $1 \beta$ activates forebrain glial cells and increases nitric oxide production and cortical glutamate and gamma-aminobutyric acid release in vivo: implications for Alzheimer's disease. Neuroscience 91, 831 842 (1999)

17 Fiorucci S, Antonelli E, Santucci L, Morelli O, Miglietti M, Federici B, Mannucci R, del Soldato $\mathrm{P}$ and Morelli A: Gastrointestinal safety of nitric oxide-derived aspirin is related to inhibition of ICE-like cysteine proteases in rats. Gastroenterology 116, 1089 - 1106 (1999)

18 Lehmann JM, Lenhard JM, Oliver BB, Ringold GM and Kliewer SA: Peroxisome proliferator-activated receptors alfa and gamma are activated by indomethacin and other non-steroidal anti-inflammatory drugs. J Biol Chem 272, 3406 - 3410 (1997)

19 Combs CK, Johnson DE, Karlo JC, Cannady SB and Landreth GE: Inflammatory mechanisms in Alzheimer's disease: inhibition of beta-amyloid-stimulated proinflammatory responses and neurotoxicity by PPARgamma agonists. J Neurosci 20, $558-$ 567 (2000)

20 Mariotto S, Menegazzi M, Carcereri de Prati A, Cuzzolin L, Adami A, Suzuki H and Benoni G: Protective effect of NO on gastric lesions and inhibition of expression of gastric inducible NOS by flurbiprofen and its nitro-derivative, nitroflurbiprofen. Br J Pharmacol 116, 1713 - 1714 (1995)

21 Santini G, Sciulli MG, Padovano R, di Giamberardino M, Rotondo MT, del Soldato P and Patrignani P: Effects of flurbiprofen and flurbinitroxybutylester on prostaglandin endoperoxidase synthases. Eur J Pharmacol 316, 65 - 72 (1996)

22 Salvemini D and Marino MH: Inducible nitric oxide synthase and inflammation. Exp Opin Invest Drugs 7, 65 - 75 (1998)

23 Schmidt $\mathrm{HH}$ and Walter U: NO at work. Cell 78, 919-925 (1994)

24 Dimmeler S, Haendeler J, Nehls M and Zeiher AM: Suppression of apoptosis by nitric oxide via inhibition of interleukin-1 betaconverting enzyme (ICE)-like and cysteine protease protein (CPP)-32-like proteases. J Exp Med 185, 601 - 607 (1997)

25 Johal K and Hanson PJ: Opposite effects of flurbiprofen and nitroxybutyl ester of flurbiprofen on apoptosis in cultured guinea-pig gastric mucous cells. Br J Pharmacol 130, 811 - 818 (2000)

26 Lu DC, Rabizadeh S, Chandra S, Shayya RF, Ellerby LM, Ye X, Salvesen GS, Koo EH and Bredesen DE: A second cytotoxic proteolytic peptide derived from amyloid beta-protein precursor. Nature med 6, 397 - 404 (2000)

27 Gervais FG, Xu D, Robertson GS, Vaillancourt JP, Zhu Y, Huang JQ, LeBlanc A, Smith D, Rigby M, Shearman MS, Clarke EE, Zheng H, Van Der Ploeg LHT, Ruffolo SC, Thornberry NA, Xanthoudakis S, Zamboni RJ, Roy S and Nicholson DW: Involvement of caspases in proteolytic cleavage of Alzheimer's amyloid- $\beta$ precursor protein and amyloidogenic A $\beta$ peptide formation. Cell 97, 395 - 406 (1999) 